DOI: $10.19195 / 0137-1150.169 .1$

\title{
Słowo wstępne od Redakcji
}

Oddajemy do rąk Czytelników 169 numer czasopisma „Slavica Wratislaviensia”, które ukazuje się nieprzerwanie od 1969 roku. Jego twórcą i założycielem był Profesor Marian Jakóbiec. Funkcje redaktorów naczelnych pełnili następnie Profesorowie: Franciszek Sielicki, Telesfor Poźniak i Milica Jakóbiec-Semkowowa. Przez pół wieku swojego istnienia pismo z organu lokalnego, prezentującego dorobek naukowy rusycystki wrocławskiej, przekształciło się w czasopismo otwarte dla wszystkich slawistów, zarówno z krajowych, jak i zagranicznych ośrodków akademickich. Obecnie ukazują się tu teksty wybitnych badaczy z Austrii, Białorusi, Chorwacji, Czech, Estonii, Hiszpanii, Japonii, Litwy, Macedonii, Niemiec, Rosji, Serbii, Słowenii, Turcji, Ukrainy i Włoch. Podkreślić należy, że zagraniczna afiliacja pojawia się nie tylko przy nazwiskach naszych autorów, lecz także członków Komitetu Redakcyjnego i Rady Redakcyjnej.

Łamy naszego czasopisma są otwarte dla artykułów naukowych z zakresu literatur, kultur, języków, historii i sztuki, myśli filozoficznej narodów słowiańskich oraz tekstów o charakterze interdyscyplinarnym, interkulturowym, wpisujących się w kontekst słowiański. W „Slavicach” publikowane są również merytoryczne recenzje książek slawistycznych oraz sprawozdania z konferencji i sympozjów naukowych.

W jubileuszowym, 50. roku istnienia czasopisma „Slavica Wratislaviensia” wydajemy numer specjalny, przygotowany we współpracy z uczelnią partnerską Uniwersytetu Wrocławskiego - Państwowym Uniwersytetem w Sankt Petersburgu. We wspólnym przedsięwzięciu naukowo-wydawniczym wzięli udział polscy i rosyjscy slawiści z obu uczelni, a także ci, którzy rozpoczętą w Petersburgu karierę naukową kontynuują obecnie w Europie Zachodniej. Doświadczeni naukowcy, uznane w świecie naukowym autorytety, ale też przedstawiciele najmłodszego pokolenia badaczy w kilkunastu artykułach zamieszczonych na stronicach niniejszego numeru przedstawiają wyniki swych literaturoznawczych i językoznawczych badań oraz dociekań. 
Członkowie Komitetu i Rady Redakcyjnej czasopisma „Slavica Wratislaviensia" są przekonani, że szerokie spektrum zagadnień podjętych w publikowanych artykułach przez reprezentantów filologii bułgarskiej, chorwackiej, czeskiej, polskiej, rosyjskiej oraz ukraińskiej, a także różnorodność zastosowanych w badaniach metodologii zainspiruje środowisko slawistyczne do dyskusji naukowych, co w sposób oczywisty i naturalny będzie sprzyjać poszerzaniu przestrzeni dialogu między kulturami, państwami i badaczami.

Ewa Komisaruk (Uniwersytet Wrocławski) 